\title{
New combinations in the genus Avicennia (Avicenniaceae)
}

\section{J. Everett}

\begin{abstract}
Everett, I. (National Herbarium of New South Wales, Royal Botanic Gardens, Sydney, N.S.W. 2000, Australia) 1993. New combinations in the genus Avicennia (Avicenniaceae). Telopea 5(4):627-629. The combinations Avicennia marina subsp. australasica and $A$. marina subsp. eucalyptifolia are made. The former provides a valid name for the taxon previously referred to as Avicennia marina var. australasica (Walp.) Moldenke, which is a name that has not been validly published. The second new combination reflects the relationships of the taxon published as A. eucalyptifolia Zipp. ex Moldenke and which had previously been published as a variety of A. officinalis; Avicennia officinalis var. eucalyptifolia is lectotypified.
\end{abstract}

The combination Avicennia marina (Forsk.) Vierh. var. australasica (Walp.) Moldenke is now widely in use in Australia (Beadle 1981; Clifford \& Specht 1979; Duke 1990, 1991; Jacobs \& Pickard 1981), whereas earlier authors mostly used A. marina var. resinifera (G. Forster) Backh.

There has been doubt over whether the former combination was validly published. It appears that, by the conditional way in which Moldenke originally expressed the combination (Moldenke 1960), he was not intending that it be taken as formal publication. Referring to Walpers' original description (1845) of A. tomentosa var. australasica, which Walpers proposed as a new name and status for $A$. resinifera G. Forster, Moldenke says '... the epithet australasica would have to be accepted as the valid name for this taxon since it is the earliest name applied to it at varietal rank. The name of the plant would then become Avicennia marina var. australasica (Walp.) Moldenke, comb. nov.' That Moldenke did not intend this to be a formal publication is indicated by his continued use of $A$. marina var. resinifera [despite the fact that it is illegitimate under Art. 11.3] throughout that paper (Moldenke loc. cit.) and in his subsequent publications concerning Avicennia (Moldenke 1967, 1968, 1977, 1978). According to Article 34.1(a) of the ICBN (1988) this is not a valid publication because the author himself did not accept the name. Therefore if this taxon is still to be referred to as a variety of $A$. marina the combination requires valid publication.

However, Duke's detailed work on Avicennia (Duke 1990, 1991) gives explicit evidence that the taxon would be more appropriately treated as a subspecies of $A$. marina. Duke (1991) left it as a variety, accepting Moldenke's publication as valid. He carried out an analysis of the species and defined three taxa that corresponded with three geographic regions: var. marina from south-western Australia, Asia and the margins of the Indian Ocean; var. eucalyptifolia in northern Australia, southern New Guinea and the southern Solomon Islands; and var. australasica in eastern and southeastern Australia, from south of Rockhampton to Adelaide, and in northern New Zealand. The distributions of these taxa overlap slightly and in each area of overlap the distinction between the respective varieties breaks down through free interbreeding. This pattern of geographic separation of the forms combined with interbreeding in areas of sympatry meets the criterion for subspecies accepted by many botanists (see Du Rietz 1930 and Stace 1980: 206-210 for a discussion of this). I am therefore providing a validly published name at the subspecific rank for the taxon referred to as $A$. marina var. australasica (Walp.) Moldenke. 
The choice of subspecific epithet is open as no epithets at this rank have been published. However, two candidates are obvious:

1. resinifera. Basionym: A. resinifera G. Forster (1786:72-73).

2. australasica. Basionym: A. tomentosa Sieber var. australasica Walpers (1845:133).

As the earlier epithet, resinifera would follow the ICBN recommendation 61A.3. However, this is not binding and so I am choosing 'australasica' in order to maintain as closely as possible current usage in Australasia (see Duke 1990, 1991; Wells 1983), and in spite of Moldenke's continued use of the varietal epithet 'resinifera' in all his publications. Therefore I here make the combination:

Avicennia marina subsp. australasica (Walp.) J. Everett, comb. et stat. nov.

BASIONYM: Avicennia tomentosa var. australasica Walp., Repert. 4: 133 (1845).

TyPIFICATION: Walpers based this variety on Forster's $A$. resinifera, which he put in synonomy. He did not refer to a type or give collection details. Some confusion arises in that he did say 'Crescit in Nova Hollandia', but this seems to be a general description of its distribution in the same style as the other six subspecies he was listing. I am, however, accepting the type of $A$. resinifera as the type of Walpers' name. This interpretation could be challenged if Walpers' specimens were available, but their whereabouts are unknown.

A. resinifera needs lectotypification as there are specimens and fragments derived from the Forster herbarium at various locations. It is worth noting that the Forsters could not have collected specimens of $A$. resinifera personally as they did not collect in New Zealand's North Island where this taxon occurs. This, however, does not affect the choice of Lectotype. Four specimens (on three sheets) were considered for lectotypification.

1. A single sprig with immature inflorescence (sheet 14630 in Thunberg's herbarium in UPS, microfiche seen), with no annotations, but which matches the description in the protologue. The Thunberg herbarium has one of the major sets of Forster specimens.

2. A sheet at the BM (BM 39306!) containing:

a. a single leaf(with one half cut and reversed) marked ' 1 ' and ' $a$ ' in two different styles of handwriting, with a reference on the back of the sheet: '1. G. Forster's Herbarium'.

b. portions of stems, four leaves and two young inflorescences marked ' 2 ' and ' $b$ ' in two different styles of handwriting, with a reference on the back of the sheet: ' 2 . Herb. Pallas from Forster'.

None of the annotations on this sheet can be matched to either of the Forsters or to Walpers or Solander (whose manuscript name Forster used).

3. a Banks and Solander specimen (BM 39305!) from New Zealand but with annotations only by Moldenke. This specimen was considered because Forster explicitly says he has referred to Solander's specimen in Banks' herbarium for inflorescence details for the description as the Forsters' specimen was collected before the flowers had opened. However, this Solander specimen has no standing as a Type element.

I have chosen the UPS 14630 specimen, being a single adequate collection that matches the protologue, as Lectotype (here designated). 
The taxon that Duke (1991) recognised as A. marina var. eucalyptifolia (Zipp.) N.C. Duke also requires a name at subspecific rank. (It should be noted that the authorship of the varietal name should have been (Valeton) N.C. Duke).

Therefore I here make the combination:

Avicennia marina subsp. eucalyptifolia (Valeton) J. Everett, comb. et stat. nov.

BASIONYM: Avicennia officinalis var. eucalyptifolia Valeton, Bull. Dep. Agric. Ind. Neerl. 10: 53 (1907).

Note: A. eucalyptifolia Zipp. ex Miq., Flor. Ned. Ind. 2: 912 (1858) was published only in synonymy.

TYPIFICATION: Valeton cited two collections from Timor, one by Zippelius and one by Spanoghe, 'G. V. Timor [ Zippelius, Spanoghe in Herb. L. B. et mus. Paris]'. As the name of the subpecies is from a Zippelius manuscript name I have selected the Leiden specimen collected by Zippelius (L 908265-623!) as Lectotype (here designated). It matches the protologue and is annotated in an unknown hand Avicennia eucalyptifolia'. There seem to be no specimens collected by Zippelius or Spanoghe from Timor at $\mathrm{P}$.

\section{References}

Beadle, N.C.W. (1981) Vegetation of Australia (Springer-Verlag: Stuttgart).

Clifford, H.T. \& Specht, R.L. (1979) Vegetation of North Stradbroke Island (University of Queensland Press: St Lucia).

Duke, N.C. (1990) Morphological variation in the mangrove genus Avicennia in Australasia: Systematic and ecological considerations. Austral. Syst. Bot. 3: 221-239.

Duke, N.C. (1991) A systematic revision of the mangrove genus Avicennia (Avicenniaceae) in Australasia. Austral. Syst. Bot. 4: 299-324.

Du Rietz, G.E. (1930) The fundamental units of biological taxonomy. Bot. Tidsskr. 24:333-428.

Forster, J.G.A. (1786) De plantis esculentis insularis oceani australis (Haude \& Spener: Berlin).

Jacobs, S.W.L. \& Pickard, J. (1981) Plants of New South Wales (Govt Printer: Sydney).

Moldenke, H.N. (1960) Materials towards a monograph of the genus Avicennia. I. Phytologia 7: 179-232.

Moldenke, H.N. (1967) Additional notes on the genus Avicennia. II. Phytologia 14(6): 326-336.

Moldenke, H.N. (1968) Additional notes on the genus Avicennia. IV. Phytologia 15(7): 470-478.

Moldenke, H.N. (1976) Additional notes on the genus Avicennia. VIII. Phytologia 4(1): 71-72.

Moldenke, H.N. (1977) Additional notes on the genus Avicennia. XI. Phytologia 6(5): 49-450.

Moldenke, H.N. (1978) Additional notes on the genus Avicennia. XII. Phytologia 40(5): 406-41.

Stace, C.A. (1980) Plant taxonomy and biosystematics (Edward Arnold: London).

Valeton, T. jr. (1907) Plantae Papuanae. Bull. Dep. Agric. Ind. Neerl. 10: 53.

Walpers, W.G. (1845) Repertorium Botanices Systematicae, vol.4: 133. (Hofmeister: Lipsiae).

Wells, A.G. (1983) Distribution of mangrove species in Australia. Pp 57-76 in H.J. Teas (ed.), The ecology and biology of mangroves. Tasks for vegetation science, vol.8 (W. Junk: The Hague) 